\title{
Monitoring and Measuring Hydraulic Fracturing Growth During Preconditioning of a Roof Rock over a Coal Longwall Panel
}

\author{
R. G. Jeffrey, Z. Chen, K. W. Mills and S. Pegg \\ Additional information is available at the end of the chapter \\ http://dx.doi.org/10.5772/56325
}

\begin{abstract}
Narrabri Coal Operations is longwall mining coal directly below a 15 to $20 \mathrm{~m}$ thick conglomerate sequence expected to be capable of producing a windblast upon first caving at longwall startup and producing periodic weighting during regular mining. Site characterisation and field trials were undertaken to evaluate hydraulic fracturing as a method to precondition the conglomerate strata sufficiently to promote normal caving behaviour at longwall startup and reduce the severity of periodic weighting. This paper presents the results of the trials and illustrates the effectiveness of hydraulic fracturing as a preconditioning technique.

Initial work was directed at determining if hydraulic fractures were able to be grown with a horizontal orientation, which would allow efficient preconditioning of the rock mass by placing a number of fractures at different depths through the conglomerate from vertical boreholes drilled from the surface. The measurements and trials were designed to determine the in situ principal stresses, the hydraulic fracture orientation and growth rate, and whether the fractures could be extended as essentially parallel fractures to a radius of at least $30 \mathrm{~m}$. Overcore stress measurements were used to determine the orientation and magnitude of the in situ principal stresses, a surface tiltmeter array was used to determine the hydraulic fracture orientation, and stress change monitoring, pressure monitoring and temperature logging in offset boreholes were used to establish the fracture growth rate, lateral extent, and that the fractures maintained their initial spacing to a radial distance of greater than 30 metres. The measurements and trials demonstrated that horizontal fractures could be extended parallel to one another to a distance of 30 to $50 \mathrm{~m}$ by injection of 5,000 to 15,000 litres of water at a rate of 400 to $500 \mathrm{~L} / \mathrm{min}$. Results from the trial allowed a preconditioning plan to be developed and successfully implemented.
\end{abstract}




\section{Introduction}

Hydraulic fracturing has been applied successfully to preconditioning of hard rock at several block caving mines [1-3] and has been used to weaken a sandstone channel over a longwall panel [4]. A recent paper documents related work in China applied to control of rock bursting [5]. In addition, hydraulic fracturing has been used to induce caving in block caving operations [1] and in longwall coal mining [6]. The work described in this paper applied hydraulic fracturing to preconditioning of a strong roof rock in order to weaken it to promote earlier caving during start up of a longwall.

Narrabri Coal Operations, located 28 km south of Narrabri, NSW, are extracting the Hoskissons coal seam using a $300 \mathrm{~m}$ wide longwall. The Digby conglomerate is 15 to $20 \mathrm{~m}$ thick and lies immediately above the seam. Geotechnical assessments of its potential to cave during longwall mining concluded that this conglomerate would not cave into the goaf until more than $60 \mathrm{~m}$ of the coal was extracted [7]. In addition, the analysis highlighted the potential for the conglomerate to pose a periodic weighting risk.

Periodic weighting occurs when the roof strata is strong enough to support itself behind the longwall face for some distance before failing suddenly as mining progresses. Failure typically occurs just ahead of the face and may cause the longwall supports to become overloaded and converge, crushing the coal on the face and posing a rock fall hazard for equipment and miners located between the face and the supports. The project described in this paper was aimed to test hydraulic fracturing as a method to precondition the conglomerate sequence and promote caving during mining.

The preconditioning test program involved initial characterisation of the in situ stresses to determine the suitability of the site for placing hydraulic fractures with a horizontal orientation. The stress measurement work was followed by a three stage program of field trials. The first stage was aimed to confirm that hydraulic fractures were able to be formed horizontally and extended for a distance of more than $30 \mathrm{~m}$ from the injection hole, given the site conditions and the available equipment. The second stage was aimed to confirm that multiple hydraulic fractures placed in close vertical proximity remained essentially parallel to each other. The third stage was aimed to confirm conditions remained suitable to form horizontal fractures in a deeper area of the mine.

The field trials used an array of monitoring boreholes drilled at various distances around a central injection hole. During the first stage of the trials, five fractures were placed through the conglomerate sequence using a straddle packer system. These fractures, which were placed at a depth of 140 to $160 \mathrm{~m}$, were monitored by a surface tiltmeter array, by boreholes offset 10 to $30 \mathrm{~m}$ from the borehole being fractured, and by stress change monitoring instruments located at $25 \mathrm{~m}$ and $60 \mathrm{~m}$ from the injection hole. Acoustic image logs of the injection hole and boreholes intersected by hydraulic fractures and core from intersected boreholes provided additional confirmation that fractures were able to be formed horizontally.

For the second stage, a second injection hole was drilled offset from the first borehole. The bottom hole locations of these two boreholes, A and J, were determined by survey to be 
separated by $6.5 \mathrm{~m}$. Five fractures were placed with a vertical spacing of $2.5 \mathrm{~m}$ and each of these was later reopened to determine intersection depths in borehole $\mathrm{C}$ and growth rate to boreholes $\mathrm{A}$ and $\mathrm{E}$ (Figure 1). As well as monitoring used in the first stage, temperature logging of borehole interesections in borehole $\mathrm{C}$ confirmed that multiple fractures were able to be formed parallel to each other over an extended distance.

The third stage of the program was conducted at the start of the third longwall panel in an area where the overburden depth is some 20-30 m deeper than at the first site. A single injection hole and two monitoring holes confirmed that hydraulic fractures were able to be formed horizontally at this location despite the greater overburden depth.

This data set provides evidence for hydraulic fracture growth to more than $30 \mathrm{~m}$ radius at a vertical spacing between fractures of $1.25 \mathrm{~m}$ and $2.5 \mathrm{~m}$, with non-symmetric fracture growth measured by the offset borehole data.

\subsection{Design approach}

Two sites were instrumented and tests were carried out to verify hydraulic fracture growth behaviour and measure the parameters needed to design the hydraulic fracture preconditioning process. Figure 1a shows the two test sites and their relative location with respect to each other and to the longwall panels at the mine. Figures $1 \mathrm{c}$ and $1 \mathrm{~d}$ contain scale drawings of the sites, with the fracturing and monitoring boreholes indicated. Both sites had a surface tiltmeter array installed and the tiltmeter instrument locations at the sites are indicated in the figures.

The second site was located over the start of Longwall 103 where the conglomerate lies at a depth of 162 to $181 \mathrm{~m}$ (see Figure 1d). The fractures at the Longwall 103 site were placed into borehole 103AA with temperature logging occurring in monitor boreholes 103ACRR and $103 \mathrm{AB}$. The temperature logging served to detect the arrival of the fractures at these boreholes and to locate their vertical positions in the boreholes.

The fractures at the Longwall 103 site were placed into borehole 103AA with temperature logging occurring in monitor boreholes 103ACRR and 103AB. The temperature logging served to detect the arrival of the fractures at these boreholes and to locate their vertical positions in the boreholes.

\section{Preconditioning plan}

By placing a number of horizontal fractures through the conglomerate layer, the mechanical behaviour of the conglomerate is modified from a thick-plate behaviour to a series of much thinner stacked plates with the aim of promoting caving. For efficient preconditioning from vertical holes drilled from the surface, hydraulic fractures are required to form horizontally as shown in Figure 1b. This fracture orientation allows efficient preconditioning from a vertical borehole because multiple fractures can be placed from each borehole. 


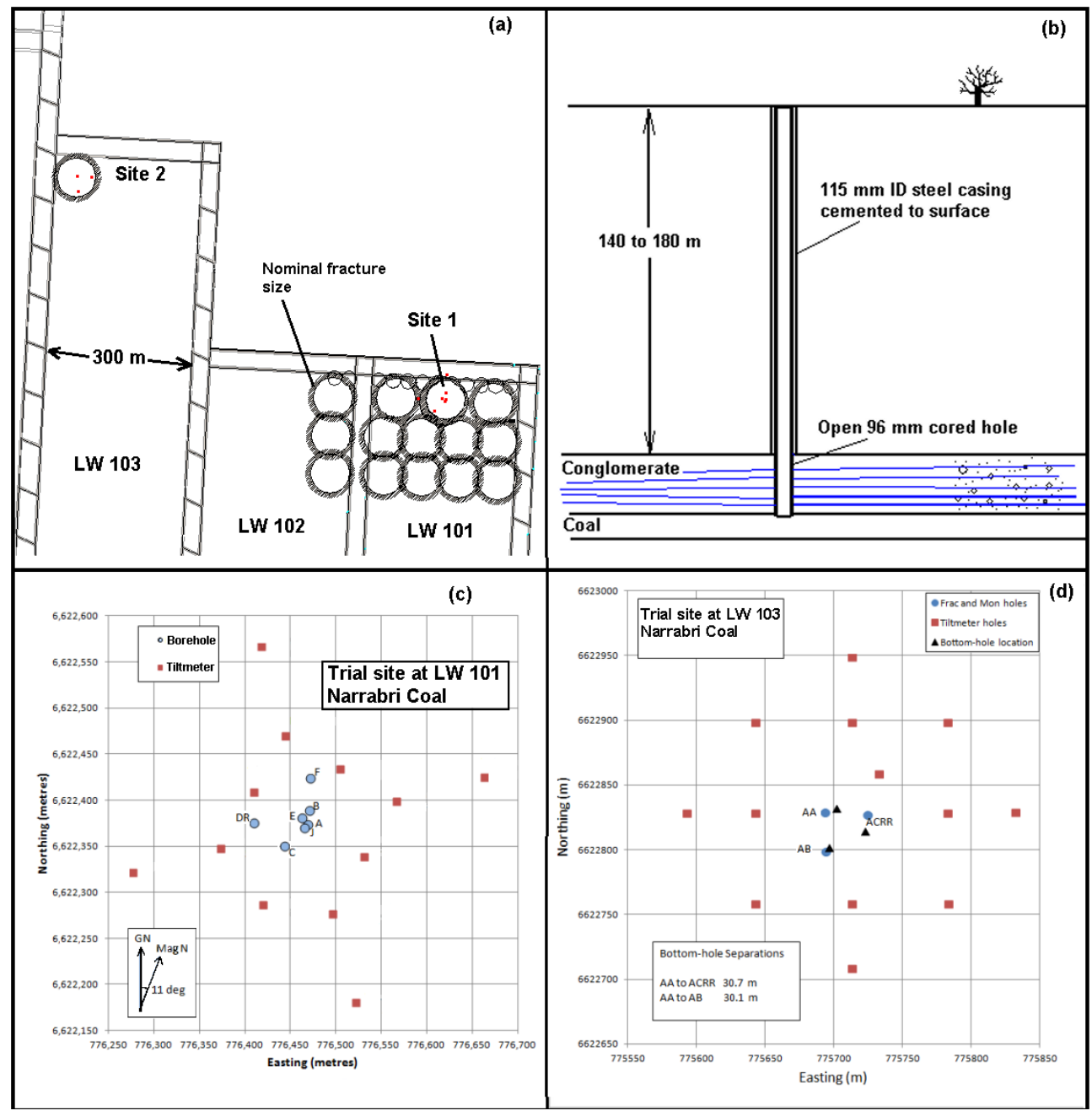

Figure 1. Test sites and borehole layout used. The drawings show (a) the location of the two test sites relative to each other and the planned underlying longwall roadways, (b) a vertical section showing the preconditioning concept, (c) the borehole layout at test site 1 over LW101 with tiltmeter locations, and (d) the borehole layout at test site 2 over LW103 with tiltmeter locations.

To confirm that this strategy would be possible in the local site conditions at Narrabri, a trial was conducted to determine the fracture orientation, growth rate, and to verify that the fractures could be extended parallel to previous fractures for a distance of $30 \mathrm{~m}$ or more. For example, boreholes spaced at $80 \mathrm{~m}$ centres require fractures to grow to $45 \mathrm{~m}$ radius with each borehole preconditioning $6,300 \mathrm{~m}^{2}$ of conglomerate and a $50 \mathrm{~m}$ spacing between holes would require fractures to grow to $30 \mathrm{~m}$ with each borehole then preconditioning 2,800 $\mathrm{m}^{2}$ of the conglomerate. These parameters would then be used to establish that horizontal fractures were 
feasible, to determine the spacing between boreholes and the volume and rate of water to inject per fracture.

\section{Test sites and measurements}

For the preconditioning to work efficiently, the minimum principal stress must be the vertical stress. This allows horizontal hydraulic fractures to be formed. In addition to being able to grow horizontal fractures, the plan required that the growth rate and ultimate size of hydraulic fractures be determined so that the vertical borehole spacing could be specified. A second important requirement for effective preconditioning was that the fractures could be initiated at regular intervals along the borehole and extended as essentially parallel fractures, with a spacing of $2.5 \mathrm{~m}$ or less, to a radius of $30 \mathrm{~m}$ or more.

\subsection{Stress measurements}

As a starting point, the vertical stress was estimated by integrating density logs from boreholes drilled in the same area. Two overcore stress measurements from a vertical borehole were then made at $145 \mathrm{~m}$ depth in the conglomerate using ANZI strain cells [8]. Each ANZI cell contains 18 strain gauges which, when bonded to the surface of a pilot hole, sense the rock strain as the gauge is overcored. Using this strain data with the rock modulus, measured in an independent test, the in situ stress acting can be found.

Analysis of this data gave an estimate of the principal stresses acting as [9]:

$\sigma_{1}=8.3 \mathrm{MPa} \pm 1.1$,

$\sigma_{2}=4.7 \mathrm{MPa} \pm 0.9$, and

$\sigma_{3}=4 \mathrm{MPa} \pm 2.4$,

with $\sigma_{3}$ the vertical stress and $\sigma_{1}$ directed N30E. The accuracy of the vertical stress in these tests is believed to have been affected by proximity to a small geological fault structure that was not recognised until later when the underground roadways were developed. The plus and minus range listed above for each stress component represents two standard deviations. For comparison, integration of a density log from a vertical borehole gave an estimate of $3.1 \mathrm{MPa}$ for the vertical stress at $145 \mathrm{~m}$ depth. Earlier biaxial overcore stress measurements [10] gave generally horizontal total stresses of $\sigma_{1}=7.7$ and $\sigma_{2}=6.0 \mathrm{MPa}$ in the conglomerate in borehole NC-098 at a depth of $156.7 \mathrm{~m}$ with both values well above the log based vertical stress magnitude of $3.35 \mathrm{MPa}$ for this depth. The value of the vertical stress from the density log was taken as an accurate value because bedding anisotropy can affect the vertical stress measured by the ANZI cell. In addition, the instantaneous shut-in pressure and offset monitor pressure data were found to correlate well with the log derived vertical stress magnitude. Taken together, the stress measurements gave an indication that horizontal fractures were likely to form, but because $\sigma_{3}$ and $\sigma_{2}$ as measured by the ANZI cell were of similar magnitude, this 
inference needed to be verified by placing full scale hydraulic fractures, monitored using tiltmeters and offset boreholes.

\subsection{Fracture asymmetry measurement}

As a series of hydraulic fractures are placed sequentually into a borehole, with the fractures placed one above the other, there is potential for them to interact. During preconditioning, the hydraulic fractures are placed at a rate of approximately one per hour. The fractures are not propped, but some injected fluid remains in the fracture and bleeds back into the well once the packers are moved uphole in preparation for the next treatment. These fractures induce a change in the stress field around them and this changed stress will affect the next fracture, potentially causing it to curve toward or away from the previous fractures and to grow asymmetrically. Figure 2 shows the stress changes measured by an ANZI strain cell located at $129.3 \mathrm{~m}$ below the surface during the placement of the first hydraulic fracture in borehole A. The peak stress observed approximately $17 \mathrm{~m}$ above the hydraulic fracture was $0.52 \mathrm{MPa}$ soon after the hydraulic fracture was placed at a depth of $146.5 \mathrm{~m}$ and this stress had reduced only to $0.26 \mathrm{MPa}$ some 1.5 hours later at which time the excess pressure in the fracture was $0.3 \mathrm{MPa}$. Once one fracture grows somewhat asymmetrically, the next fracture is likely to find it easier to grow in a way such that it grows so as to avoid the residual vertical stresses created by the previous fracture and its centre of volume is offset relative to the centre of volume of the previous fracture.

The movement of the fracture centre of volume can, in principle, be detected by analysis of the tilt data [11] and also by noting the time of intersection of the fracture with the monitoring boreholes. Both of these methods of detecting asymmetry were used for the fracturing work carried out at the test sites.

Figures 3 and 4 summarise data recorded during fracture $4 \mathrm{~J}$ and $7 \mathrm{~J}$, showing both the injection pressure at borehole $\mathrm{J}$ and the pressure response in the monitored boreholes. During fracture $4 \mathrm{~J}$, single packers were installed at the top of the conglomerate, set at $140.9 \mathrm{~m}$ to the bottom of the packer rubber, in monitor boreholes $\mathrm{C}$ and $\mathrm{E}$ and a vibrating wire piezometer was located at $146.0 \mathrm{~m}$ in monitoring borehole A. The piezometer was intalled in a coarse sand-filled section of the borehole with a grout plug at the conglomerate base and a second grout plug placed from the top of the conglomerate to the surface. The packers each contained a mandrel that connected through the packer to the open hole below. This pressure was transmitted to the surface via a $6 \mathrm{~mm}$ ID high pressure hose which was connected to a pressure transducer for logging. The pressures shown for the injection pressure and for boreholes $\mathrm{C}$ and $\mathrm{E}$ have had the hydrostatic pressure to the depth of the injection point in borehole J added to them to give an approximate bottom hole pressure. The calibrated piezometer output gives a direct bottom hole pressure at its set depth in borehole A.

Fracture 4J was carried out by straddling a slot at $151.8 \mathrm{~m}$ in borehole $\mathrm{J}$. The fracture grew into boreholes $\mathrm{E}, \mathrm{C}$ and then $\mathrm{A}$ as indicated by the pressure responses shown in Figure 3. In order to fit a circular fracture to this implied growth, the centre of the fracture needs to be located, 
WCL5 - Frac 1

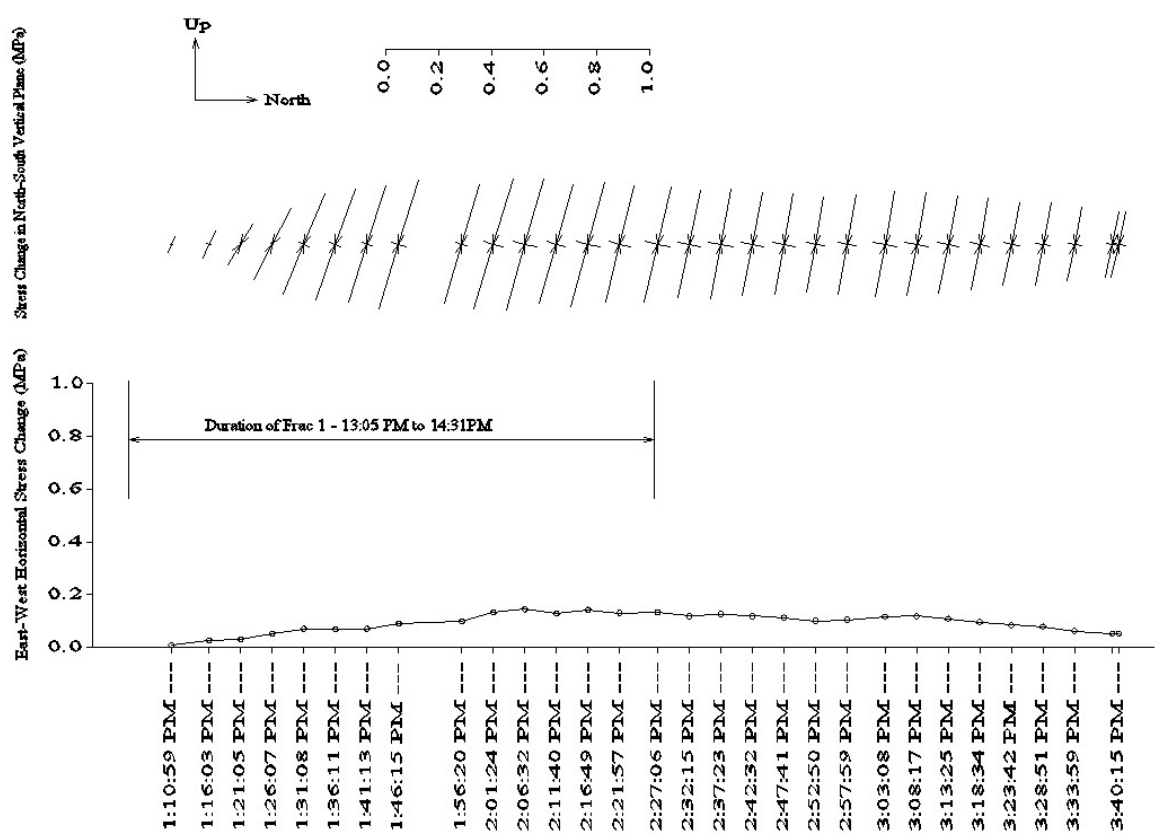

Figure 2. Stress change recorded during fracturing of borehole $A$. The fracture was shut-in at 14:31 (2:31 pm) and flowed back at 17:20 (5:20 pm) so pressurised fluid was contained in the fracture during the entire period of this plot. Fracture closure occured at 16:08 (4:08 pm).

at the time the fracture grows through borehole $\mathrm{A}$, at a point $15 \mathrm{~m}$ west of borehole $\mathrm{J}$. The intersection The intersection time for borehole A corresponds to a pressure at the piezometer of $3.47 \mathrm{MPa}$, which is just above the vertical stress magnitude. However, the earlier rise in pressure at 9:56 could be an indication of an earlier intersection, although the pressure at that time only reaches a value of $2.56 \mathrm{MPa}$. If water was being lost out of borehole $\mathrm{A}$ above the fracture depth (near $151.8 \mathrm{~m}$ ), perhaps into an existing hydraulic fracture connected into borehole J above the packers, then this flow through the coarse sand would make the pressure in borehole A non-uniform and would result in the piezometer reading a pressure lower than the pressure in the fracture located approximately $5.8 \mathrm{~m}$ below it. However, the coarse sand used has an estimated permeability of 2,000 Darcies. A flow of $17 \mathrm{~L} / \mathrm{min}$ through $5 \mathrm{~m}$ of this sand pack would result in a steady-state pressure drop of only 0.1 MPa. An earlier intersection time would support a less asymmetric fracture shape development and does highlight a possible source of error in picking intersection times based on pressure measured at borehole A. 
Data collected during fracture 7J is summarised in Figure 4. The intersection with boreholes E and A occurred close together in time. In this case, the fracture depth $(146.8 \mathrm{~m})$ is very nearly the same as the piezometer depth $(146.0 \mathrm{~m})$ in borehole $\mathrm{A}$, which minimises the issue of water flowing through the sand pack affecting the piezometer pressure. During this fracture treatment, temperature logging was carried out in borehole $C$, which was open at the borehole collar. The intersection time of the fracture into borehole $C$ is indicated in Figure 4 and the temperature log is shown in Figure 5. The temperature logging method involved first cooling the water in the borehole by pumping ice water through a $20 \mathrm{~mm}$ diameter polypipe to the bottom of the borehole. A cooled condition of $10^{\circ} \mathrm{C}$ or less was typically achieved. The rock temperature at $145 \mathrm{~m}$ is approximately $23^{\circ} \mathrm{C}$ at this site and the water injected into a hydraulic fracture is quickly warmed to this temperature. Therefore, intersection locations were found by noting the depth where warm fluid was entering the monitored borehole and the first arrival of warm fluid into the hole is an indication of fracture growth rate. The sensor located at 158.5 $\mathrm{m}$ in borehole $\mathrm{C}$ started to increase in temperature at 11:50 (see Figure 5 and by 11:57 two warm peaks had been established at $145.5 \mathrm{~m}$ and $147.9 \mathrm{~m}$. Early and weaker warming events may be associated with fluid being expelled from previously placed hydraulic fractures which are squeezed more tightly shut as the propagating hydraulic fracture interacts with them. The stronger warming events at 11:56:08 are therefore taken as corresponding to the intersection time.

Intersections from a number of fractures placed into borehole $\mathrm{J}$ have been used to define the fracture growth asymmetry. Figure 6 shows the range of fracture asymmetry measured by intersection data from this analysis. Only circular fractures are considered in Figure 6, although it is believed unlikely that the fractures were perfectly circular. However, if the fractures are allowed to take non-circular shapes, the range of centre locations and fracture sizes that can be fitted to the intersection data is increased significantly.

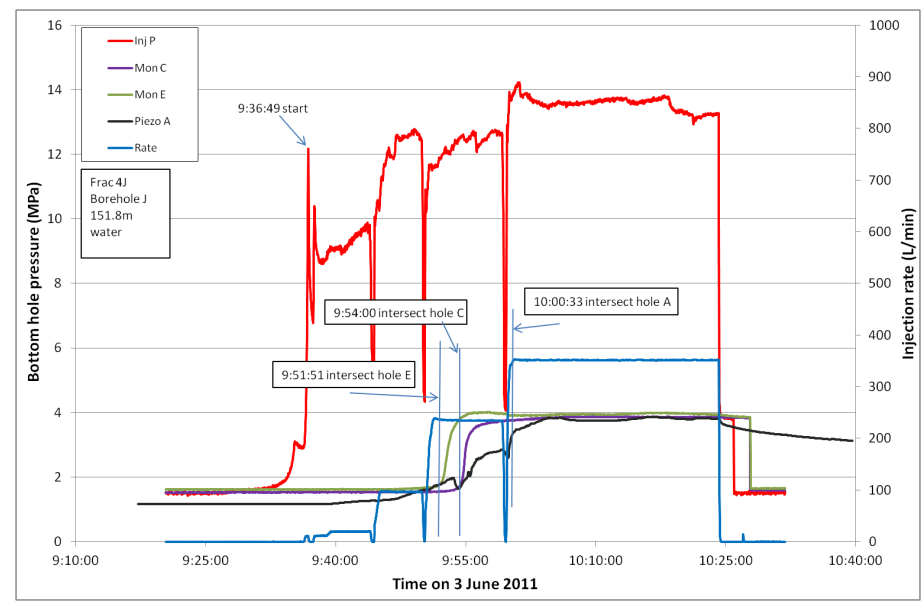

Figure 3. Data summary plot for fracture 4J, which includes pressure monitoring data in boreholes $A, E$, and C. 


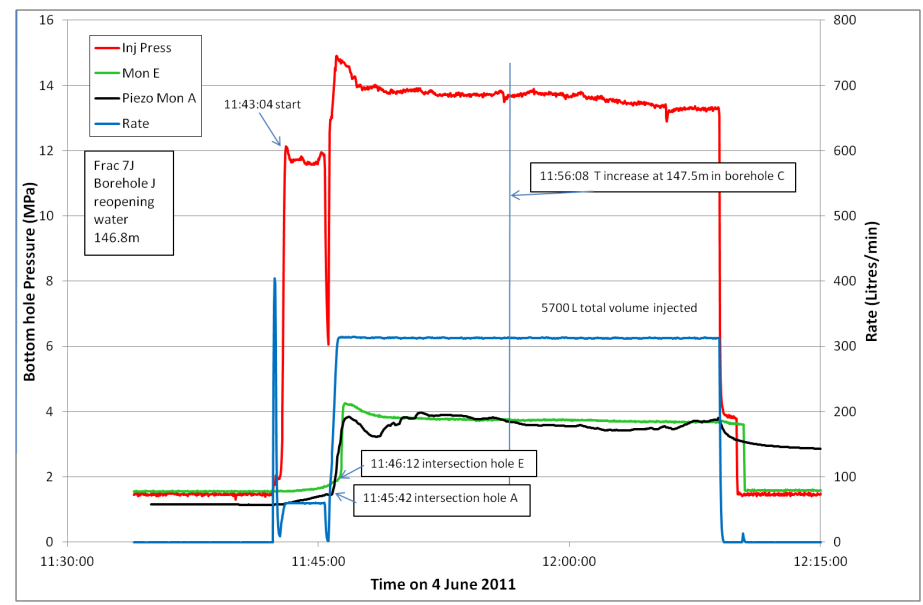

Figure 4. Data summary plot for fracture $7 \mathrm{~J}$, including pressure monitoring data in boreholes $\mathrm{A}$ and $\mathrm{E}$. Temperature was monitored in borehole C during this fracture (see Figure 5).

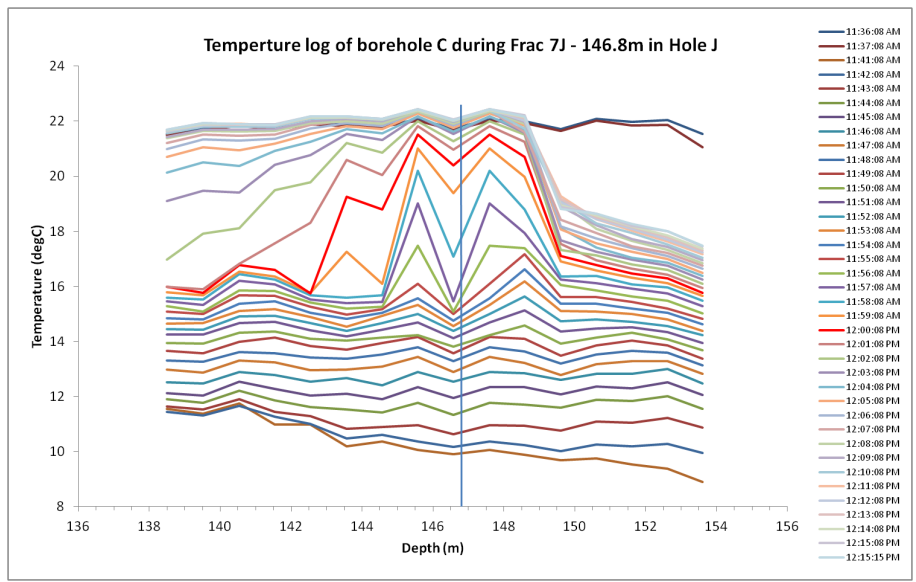

Figure 5. Temperature variation with depth in borehole $\mathrm{C}$ during fracture $7 \mathrm{~J}$. A line has been drawn at $146.8 \mathrm{~m}$ to indicate the nominal depth of fracture $7 \mathrm{~J}$ in hole $\mathrm{J}$.

\subsubsection{Asymmetry from analysis of tilt data}

By representing the fracture in the forward model as a displacement discontinuity (DD) singularity within a homogeneous, isotropic linear-elastic half-space and using a Bayesian probabilistic inversion approach, the fracture volume, orientation, and location of the fracture center-of-opening versus time have been estimated by analyzing the tilt measurements. This provides considerable insight into the geometry and development of the hydraulic fractures. 
The displacement field produced by a DD of the intensity $D_{j}$ across a surface $S$ (the hydraulic fracture) in a uniform elastic half space can be expressed as [12]

$$
u_{i}(x)=\iint_{S} D_{j}\left(x^{\prime}\right)\left[\delta_{j k} \lambda \frac{\partial U_{i l}}{\partial x_{l}^{\prime}}+\mu\left(\frac{\partial U_{i j}}{\partial x_{k}^{\prime}}+\frac{\partial U_{i k}}{\partial x_{j}^{\prime}}\right) v_{k}\right] d s
$$

where $u_{i}(x)$ is the displacement in the $x_{i}$ direction at a point $x . U_{i j}\left(x, x^{\prime}\right)$ is the ith component of displacement at $x$ due to a point force of unit magnitude acting in the $x_{j}$ direction at a point $x^{\prime}$ on $S$ within an elastic half space. $v$ is the normal to $S$ at point $x^{\prime} . \lambda$ and $\mu$ are the Lame coefficients for the elastic rock material.

The measured tilt angles are related to the displacement gradients by

$$
\omega_{1}=\frac{\partial u_{1}}{\partial x_{3}}-\frac{\partial u_{3}}{\partial x_{1}} \omega_{2}=\frac{\partial u_{2}}{\partial x_{3}}-\frac{\partial u_{3}}{\partial x_{2}}
$$

For a horizontal hydraulic fracture which grows symmetrically with respect to the borehole, the fracture centre is taken to be at the injection point. Sometimes, asymmetric growth of the hydraulic fracture can occur. In this case, the fracture centre will move away from the injection point as the fracture grows. It is assumed that the fracture is planar, so the injection point and the fracture centre must remain in the fracture plane.

It has been shown that in most cases the analysis of tilt data allows for a robust estimation of fracture volume and orientation (dip and strike) [13, 11]. To investigate the movement of the fracture centre, consider a DD singularity centered at $\left(x_{c}, 0,0\right)$ in an infinite elastic body. Given an offset, which for simplicity we specify as along only the $\mathrm{x}$ axis, of $\left(\Delta x_{c^{\prime}}, 0,0\right)$ for the DD center, the tilt component can be obtained by using a Taylor series expansion as

$$
\omega_{1}^{D D}\left(x_{c}+\Delta x_{c}\right)=\omega_{1}^{D D}\left(x_{c}\right)\left[1+\left(\frac{\Delta x_{c}}{r}\right) g_{1}+\left(\frac{\Delta x_{c}}{r}\right)^{2} g_{2}+O\left(\frac{\Delta x_{c}}{r}\right)^{3}\right]
$$

where $r=\sqrt{\left(x-x_{c}\right)^{2}+y^{2}+z^{2}}$ denotes the distance between the point $(x, y, z)$ and the DD center $\left(x_{c}, 0,0\right)$, and the functions $g_{1}$ and $g_{2}$ are of order $O(1)$.

Eq. 3 shows that the estimation of fracture center movement is coupled with the tilt measured at $x_{c}$ which depends on the fracture orientation and volume. The fracture center movement $\Delta x_{c}$ is difficult to be resolved when it is far less than the observation distance $r$.

Two synthetic examples are presented here to show the effect of fracture center movement on the estimation of fracture volume and orientation. In the first example, the synthetic tilt data are generated by using a point DD singularity with a dip of $20^{\circ}$ and a dip orientation of N160 0 in an elastic half-space. The fracture center is fixed at $20 \mathrm{~m}$ east of the injection point. The fracture volume increases linearly with time, reaching a maximum of $6 \mathrm{~m}^{3}$ at 40 minutes. Then the generated tilt data are used to infer the fracture geometry by using a Bayesian probablistic 
inverse approach, assuming that the fracture is centered at the injection point. The predicted fracture dip direction and dip are shown in Figure 7. As we can see, an incorrect assumption on the fracture center location leads to a poor prediction of the fracture orientation.

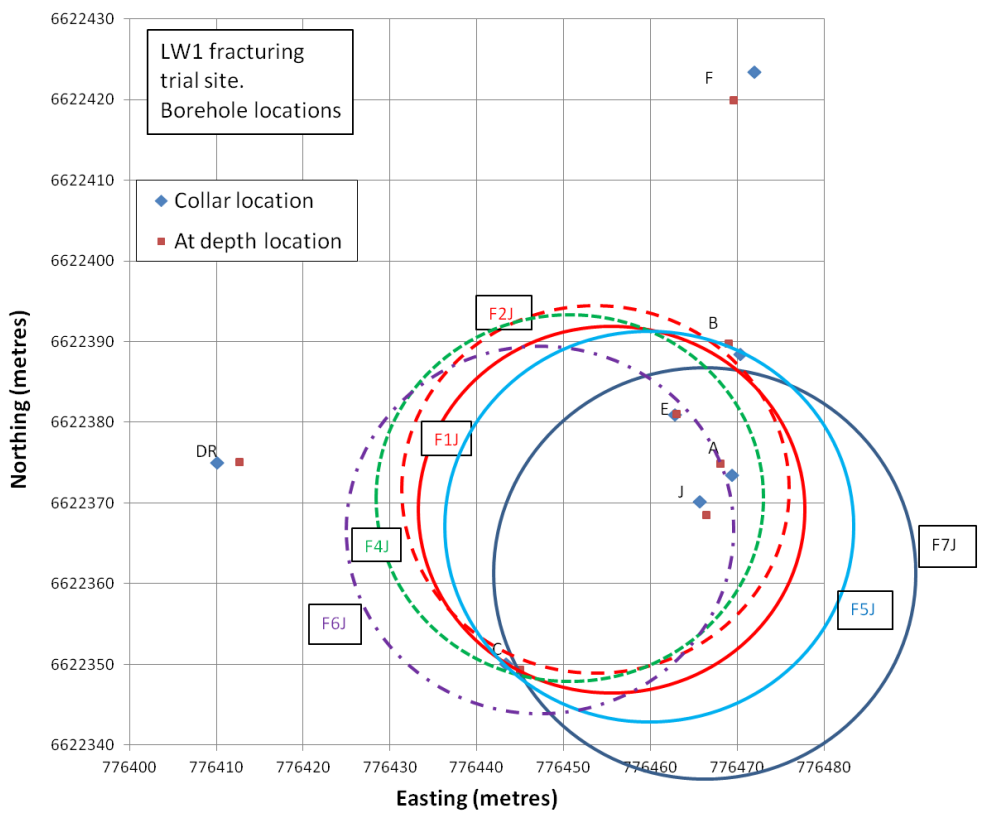

Figure 6. Longwall 101 trial site showing approximate fracture asymmetry inferred from intersection data for fractures placed into borehole J. Fractures are drawn at the time of the last intersection and in most cases injection stopped shortly after this time.

In the second example, the fracture has a dip of $10^{\circ}$ and a dip orientation of N1600 centered at the injection point. The synthetic tilt data are used to infer the fracture geometry (fracture volume and dip orientation) and the fracture center movement (see Figure 8) by specifying the frature dip of $20^{\circ}$. It can be seen from Figure 8 that the incorrect constraint of the fracture dip results in an incorrect inferred movement of the fracture center.

Table 1 contains the fracture center location inferred from analysis of the tiltmeter data for a number of fractures in borehole J. Because the location of the center of volume is correlated to the dip and dip direction, the analysis was carried out for a case where both the orientation and the center of volume were found with no constraint and then again for the case where the fracture was constrained to be horizontal.

Of the fractures listed in Table 1 and also drawn in Figure 6 with their locations based on intersection data, only fracture $7 \mathrm{~J}$ has an inferred center of volume that is somewhat consistent for the two methods. The tiltmeter results, which correspond to a time of 15 minutes from the start of injection, generally indicated less movement of the fracture center than the intersection data suggests. The inferred dip magnitude from the tiltmeter analysis is in the range of $40^{\circ}$ for 
fractures 1J, 4J, and 6J. This dip magnitude is larger by a factor of at least two than dips inferred from tilt data for fracturing carried out in other boreholes in this area (see Table 2, average dip $15.9^{0}$ ) and does not agree with the intersection data either. The reason for these relatively large dips for this series of fractures, which are thought to be in error, is not know but may be related to small movements induced on faults present in this portion of the longwall.
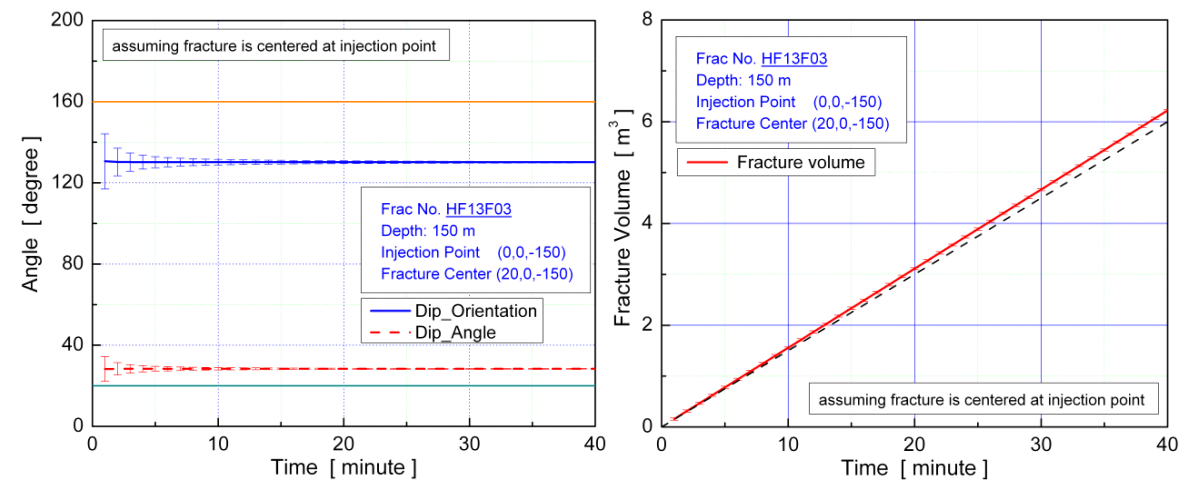

Figure 7. The predicted fracture geometry calculated with an assumed fracture center located at the injection point when in fact it is offset by $20 \mathrm{~m}$.
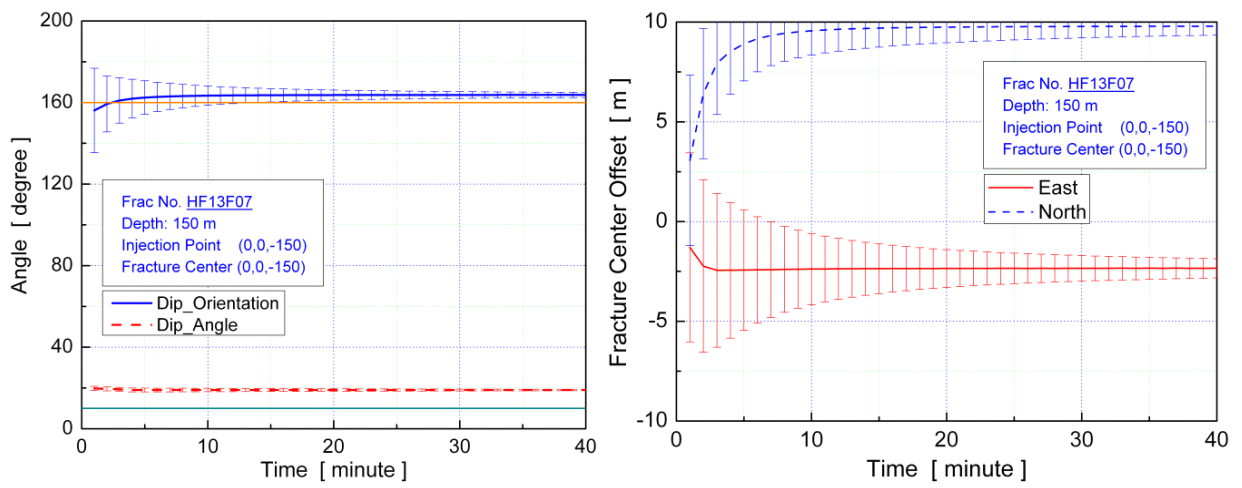

Figure 8. The predicted fracture geometry and center movement obtained by specifying the fracture has a dip of 200 when in fact the dip is 100 . 


\begin{tabular}{cccc}
\hline Fracture & $\begin{array}{c}\text { Northing offset } \\
\text { (meters) }\end{array}$ & $\begin{array}{c}\text { Easting offset } \\
\text { (meters) }\end{array}$ & $\begin{array}{c}\text { Dip/Dip Direction } \\
\text { (degrees) }\end{array}$ \\
\hline $1 \mathrm{~J}$ & 0 & 0 & $C_{-} 0$ \\
\hline JJ & +0.5 & 0 & $38 / 180$ \\
\hline $4 \mathrm{~J}$ & 0 & 0 & $C_{-} 0$ \\
\hline 4J & 0 & 0 & $38 / 160$ \\
\hline $6 \mathrm{~J}$ & -1.0 & 0 & $C_{-} 0$ \\
\hline 6J & +4.0 & +2.0 & $40 / 160$ \\
\hline $7 \mathrm{~J}$ & -5.0 & +1.0 & $C_{-} 0$ \\
\hline $7 \mathrm{~J}$ & -1.0 & +2.0 & $25 / 170$ \\
\hline
\end{tabular}

Table 1. Centre location of fractures relative to borehole location based on tiltmeter data. Fractures with a dip of $C_{-} 0$ were constrained to be perfectly horizontal.

\begin{tabular}{|c|c|c|c|}
\hline \multirow[t]{2}{*}{ Borehole } & \multirow[t]{2}{*}{ Fracture } & \multicolumn{2}{|c|}{ Orientation } \\
\hline & & Dip & Dip direction \\
\hline \multirow[t]{2}{*}{ A } & 2 & 200 & 1850 \\
\hline & 4 & 100 & 1800 \\
\hline \multirow[t]{2}{*}{ 101AW } & 1 & 220 & 3300 \\
\hline & 5 & 20 & 1400 \\
\hline \multirow[t]{2}{*}{ 101BAR } & 1 & 200 & 700 \\
\hline & 3 & 20 & 50 \\
\hline \multirow[t]{3}{*}{ 101ASR } & 1 & 300 & 1900 \\
\hline & 7 & 200 & 1850 \\
\hline & 10 & 250 & 1900 \\
\hline 102AA & 1 & 200 & 3000 \\
\hline \multirow[t]{2}{*}{ 101AUR } & 2 & 350 & 1400 \\
\hline & 3 & 150 & 1650 \\
\hline $102 \mathrm{AE}$ & 2 & 100 & 650 \\
\hline $102 A D$ & 1 & 100 & 1900 \\
\hline \multirow[t]{2}{*}{$101 \mathrm{AL}$} & 1 & 80 & 2700 \\
\hline & 3 & 50 & 3000 \\
\hline
\end{tabular}

Table 2. Variation of dip and dip direction as determined by tiltmeter analysis.

For comparison, the dip direction and dip for fracture 3 at the Longwall 103 test site is shown in Figure 9a with the tilt vertors from this fracture at the end of the injection shown in Figure $9 \mathrm{~b}$. The $20^{\circ}$ dip is believed to be too large and is likely to be reflecting some movement of the centre of opening of the fracture. 


\subsection{Fracture growth measurement}

Tiltmeter monitoring [11-15], stress change monitoring [16], offset borehole measurements [17], and fracture growth modelling using a numerical hydraulic fracturing model were used to obtain the fracture growth rate as a function of injection rate and volume. The tiltmeter data provided a confirmaton that the hydraulic fractures were essentially horizontal in orientation. Stress change monitoring using ANZI cells installed in boreholes B and F (Figure 1), indicated fracture growth below these locations during injections into borehole A.

The primary data used to establish the hydraulic fracture growth rate were timing of the first arrival intersection events at offset boreholes. These data were filtered to remove the most extreme asymmetric growth cases so that an axisymmetric hydraulic fracture model could be used to match the measured growth. By matching several different measurements, the model was calibrated for the conditions at the Narrabri site. The calibrated model was then used to produce a set of time versus fracture radius curves for three different injection rates and these were then used for choosing a rate and volume that would produce a fracture size needed in the preconditioning work. A borehole spacing compatable with the ultimate size of the fractures was selected as part of this process. Figure 10 contains the growth curves generated by the numerical fracture model with several points indicating measured intersection events, for fractures placed using similar rates, also shown.

(a)

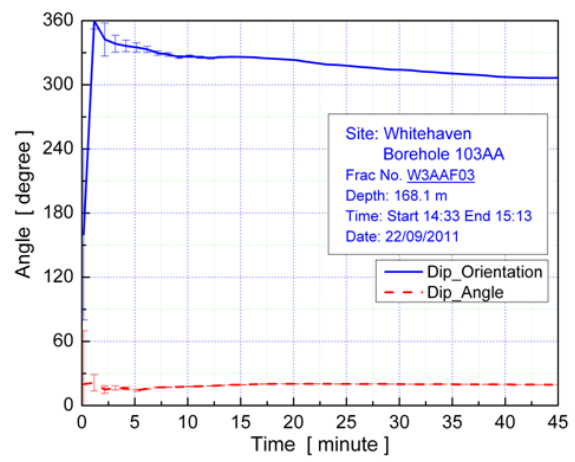

(b)

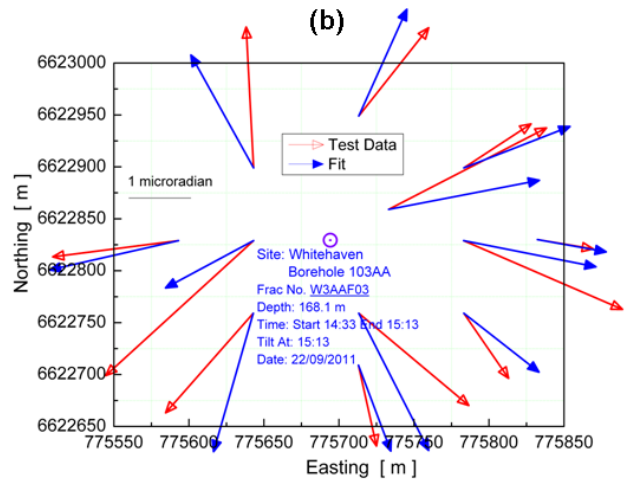

Figure 9. Analysis of tilt data from fracture 3 at the LW3 site. The fracture was interpreted to dip to the north at $20^{\circ}$. The tilt vectors at the end of the injection are consistent with a horizontal fracture deformation field.

The curves calculated were fitted to the higher growth rate data represented by Frac 2 in borehole 101AM. In this case, the fracture grew through two monitoring holes located $30 \mathrm{~m}$ to the east and $30 \mathrm{~m}$ to the west of 101AM. The growth for this fracture was therefore thought to be fairly symmetric. The other measurements shown are from the trial site over Longwall 103 where injection occured into borehole 103AA and monitoring occurred at two offset boreholes. These points illustrate the variability in the measured growth data with asymmetric growth 
being a primary cause. For example, Frac 3 in 103AA grew through one monitoring borehole located $31 \mathrm{~m}$ to the east of the injection borehole after 11 minutes, but required 23 minutes to grow through the second monitor hole located $30 \mathrm{~m}$ to the south of the injection borehole. On average, growth of the fractures seemed to be somewhat slower at the Longwall 103 site than at the Longwall 101 sites. Using these data, the treatments for preconditioning of the main longwall panels were designed to inject water at $500 \mathrm{~L} / \mathrm{min}$ for 25 minutes each which, according to the growth curves in Figure 10, would produce fractures of approximately $45 \mathrm{~m}$ radius. The boreholes over the main Longwall 101 panel were drilled using an $80 \mathrm{~m}$ spacing.

\subsection{Fracture vertical spacing measurement}

To achieve the intended degree of treatment of the conglomerate, it was desirable to create hydraulic fractures that were parallel to one another so that the massive conglomerate layer was divided by the fractures into thinner and mechanically weaker system of layers. Work by

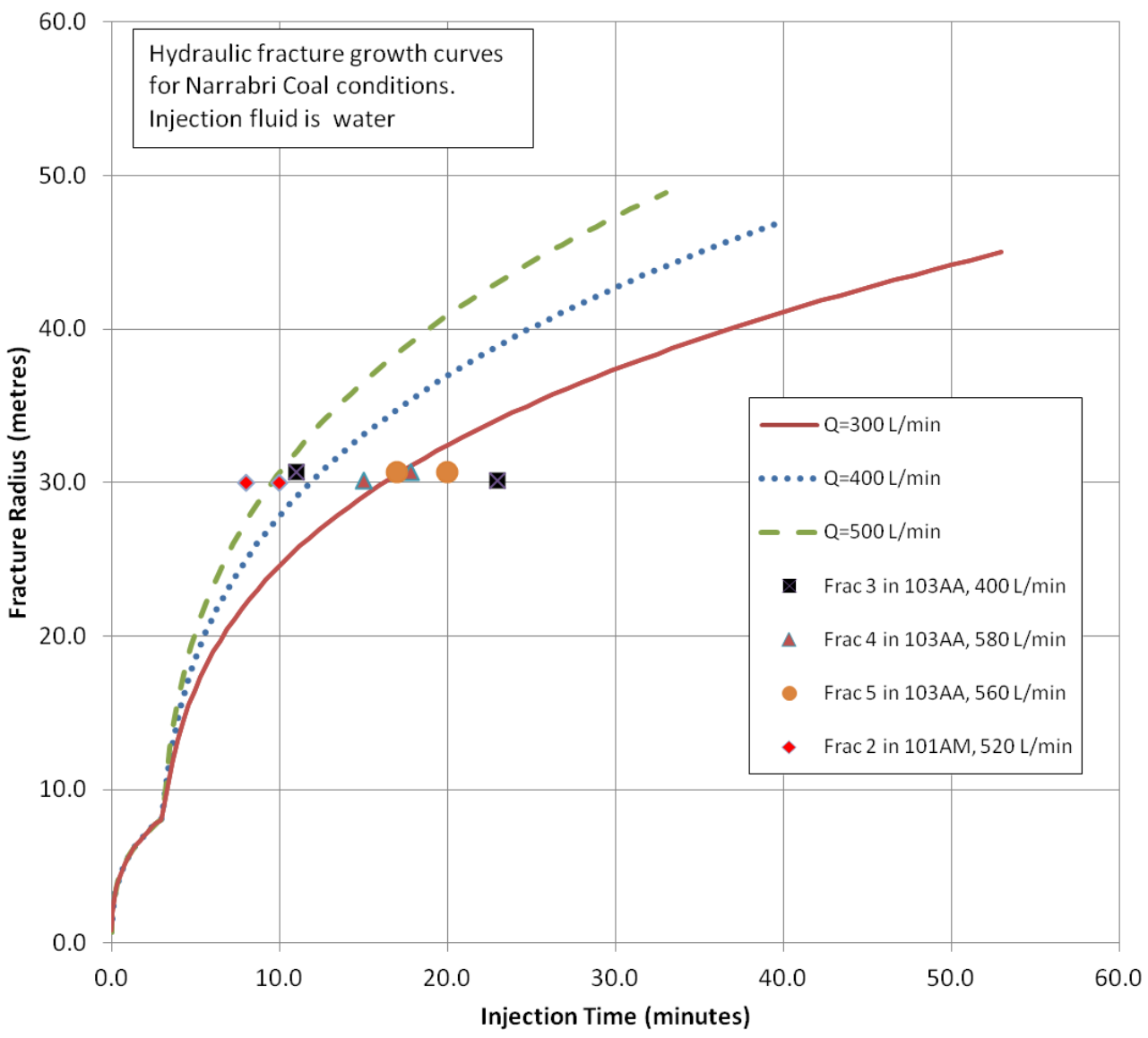

Figure 10. Growth measurements with curves generated by a numerical fracturing model. 
[3] has shown that fractures grown through rock blocks in the laboratory are sensitive to initiation conditions. This laboratory work showed that fractures that initiated by splitting the borehole and then reoriented to become transverse to the borehole, were found to have much less regular spacing away from the borehole with growth into adjacent fractures commonly occurring (see [18] for additional details of the laboratory determined fracture paths). In contrast to this, if the fractures were initiated from slots or notches cut into the borehole, the fractures initiated and continued to grow in the same plane, as transverse fractures. The laboratory work showed that these fractures were spaced more regularly and they tended to extend into the far-field as parallel fractures. The initiation sites in the vertical boreholes at Narrabri were therefore notched using a sand and water abrasive jetting method. By rotating the jetting tool slowly, a circumferential slot was cut to act as a stress concentration point for fracture initiation.

A separate laboratory study, described in [19], presents results verifying a theory of closely spaced hydraulic fracture growth. The theory applies to fractures that are placed successively, one after the other and can be applied to predicting if the next fracture in a sequence will curve towards or away from the previous fracture. To make a prediction, the size and residual width of the previous fracture must be known. In addition, the rock elastic properties, the coefficient of friction for sliding of the hydraulic fracture surfaces, the stress field, and the injection rate and fluid viscosity are required. These parameters are then inserted into expressions for several dimensionless groups whose value then determine the type of curving to expect (see [19] for details). The calculation applied using parameters for the conditions at Narrabri, predict that essentially no curving of the hydraulic fracture will occur and that the fractures should grow parallel to one another.

Intersection of the fractures with offset pressure monitoring boreholes, as shown in the data contained in Figures 3 and 4, confirmed an approximately horizontal fracture orientation, but did not confirm that the fractures were growing parallel to one another. Fractures may have been growing into an adjacent fracture, for example, or growing with divergent paths which would leave wedge-shaped block of unfractured rock. The acoustic image logs run before and after fracturing were not able to detect the horizontal fractures in the horizontally bedded conglomerate. Two fracture traces, both dipping at approximately $10^{\circ}$ to the west are visible at 149.9 and $150.1 \mathrm{~m}$ in the acoustic image of borehole J before it was fractured. These may be hydraulic fractures generated during fracturing of borehole A, but no other fracture traces can be seen in this image suggesting the hydraulic fractures are not wide enough to be seen by this method.

The core from borehole J, which was drilled after borehole A was hydraulically fractured, was examined in order to detect the fractures placed into borehole A. Several horizontal fractures were logged with four of them showing rotational shearing caused by the core rotating at that point during drilling. Such rotationally sheared fractures are normally fairly rare and have, in this case, been taken as indications of the location of the hydraulic fractures. Table 3 compares the fracture depths in borehole A with the depths of the logged rotationally sheared fractures in borehole J. The rotated core breaks in the core from borehole J are found to correspond 


\begin{tabular}{ccc}
\hline Fracture & $\begin{array}{c}\text { Depth of initiation } \\
\text { (metres) }\end{array}$ & $\begin{array}{c}\text { Depth from core } \\
\text { (metres) }\end{array}$ \\
\hline 1 & 146.4 & 146.1 \\
\hline 2 & 149.8 & 150.0 \\
\hline 3 & 140.2 & 140.2 \\
\hline 4 & 144.7 & 151.9 \\
\hline 5 & 151.5 & \\
\hline
\end{tabular}

Table 3. Comparison of fracture initiation depths in borehole A with rotated core breaks from borehole J. closely to the depths of initiation of the fractures in borehole A, suggesting nearly horizontal fracture orientation. This conclusion is supported by other intersection data such as that shown in Figure 4 for fracture 7J, which grew from borehole J into borehole C, $28.8 \mathrm{~m}$ away, and was located by termperature logging to be within plus or minus $1 \mathrm{~m}$ of the initiation depth (an apparent $\operatorname{dip}$ of $2^{\circ}$ ). The horizontal distances between the injection boreholes and the monitoring boreholes are listed in Table 4.

\begin{tabular}{ccc}
\hline Borehole & A & J \\
\hline A & $0.0 \mathrm{~m}$ & $6.5 \mathrm{~m}$ \\
\hline B & $14.9 \mathrm{~m}$ & $21.3 \mathrm{~m}$ \\
\hline C & $34.4 \mathrm{~m}$ & $28.8 \mathrm{~m}$ \\
\hline DR & $55.3 \mathrm{~m}$ & $54.1 \mathrm{~m}$ \\
\hline E & $8.0 \mathrm{~m}$ & $13.0 \mathrm{~m}$ \\
\hline F & $45.1 \mathrm{~m}$ & $51.4 \mathrm{~m}$ \\
\hline$J$ & $6.5 \mathrm{~m}$ & $0.0 \mathrm{~m}$ \\
\hline
\end{tabular}

Table 4. Horizontal distance in metres between boreholes $\mathrm{A}$ and $\mathrm{J}$ and other boreholes at the site.

Inversion of the tiltmeter data cosistently produced dips of $10^{\circ}$ to $30^{\circ}$. These larger dips seem to be in error in light of the nearly horizontal orientations obtained from intersection data with temperature logging. Figure 11 shows the fracture spacing implied by the temperature logging carried out in borehole $\mathrm{C}$ during fracturing of borehole J. Figure 12 shows fracture vertical spacing measured while fracture borehole 101AM while temperature logging in borehole 101AN. Both data sets illustrate the essentially parallel growth of the hydraulic fractures between these holes, confirming the prediction made from the theory of closely spaced fracture growth. Holes AM and AN lie along the startup roadway running at an azimuth of $273^{\circ}$ with respect to grid north while the line connecting borehole $\mathrm{J}$ to $\mathrm{C}$ is oriented at an azimuth of $231^{\circ}$. Borehole AM is approximately $85 \mathrm{~m} \mathrm{NW}$ of borehole J. Therefore, if these sections are taken as representative, the hydraulic fractures are essentially horizontal and maintain their initiation vertical spacing over more than $30 \mathrm{~m}$ of growth. 


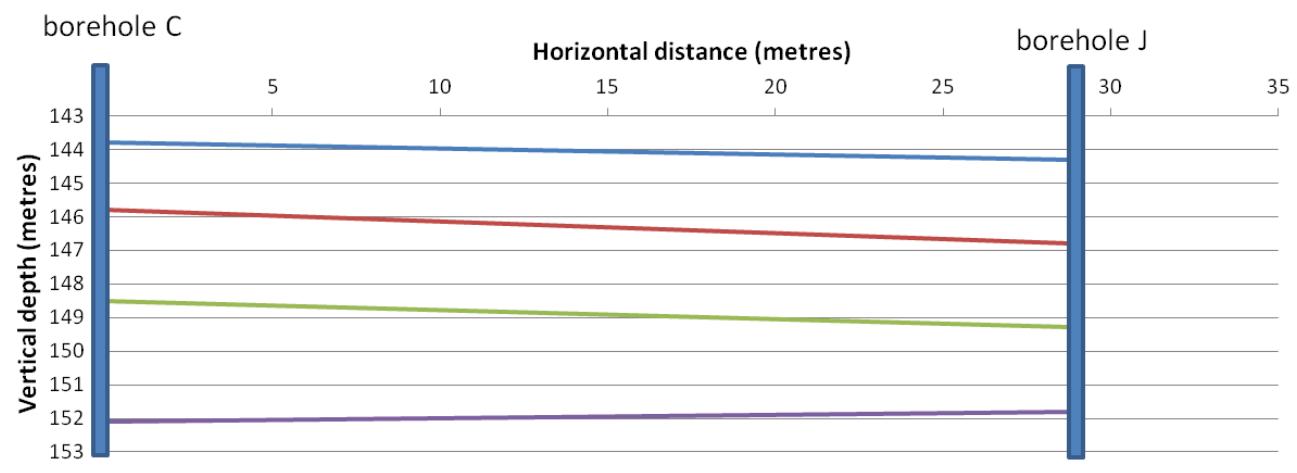

Figure 11. Fracture orientation and spacing implied by intersection and temperature logging data collected in borehole C during fracturing of borehole J. Fractures were placed at $2.5 \mathrm{~m}$ vertical spacing in borehole J.

\section{Caving behaviour}

The longwall started retreating on 12 June 2012 with a windblast management plan in place that required additional precautions to be used during mining until the caving commenced and the goaf developed. If the goaf behind the longwall face had not formed by the time the face had retreated to $25 \mathrm{~m}$ from the start position, additional work to induce caving was planned. However, the conglomerate caved, starting at the centre of the panel and progressing toward both gate roadways, after $24 \mathrm{~m}$ of retreat. This was a significant improvement over the estimated distance of more than $60 \mathrm{~m}$ for caving to start that was made based on modeling studies of the untreated conglomerate.

Beyond the startup area for a distance of $200 \mathrm{~m}$, the conglomerate was preconditioned using boreholes located on approximate $80 \mathrm{~m}$ centres. The intensity of fractures placed in this main part of the longwall panel was approximately 25 percent of that applied along the startup section. A $100 \mathrm{~m}$ wide window was then left with no preconditioning to allow comparison of the fractured and unfractured conglomerate caving behavior. Mining under this section of conglomerate demonstrated that the preconditioning reduced the intensity of the periodic weighting events, but the events that still occurred were more random under the preconditioned roof. When mining under the conglomerate that was not preconditioned, weighting events could be anticipated to occur at regular intervals of about $15 \mathrm{~m}$ of longwall retreat. Therefore, adjustments to the daily longwall extraction plans were made so that any slowing or halting of mining was avoided when approaching an anticipated weighting event. Using this modified mining strategy, mining was continued without using preconditioning for the rest of Longwall 101. 


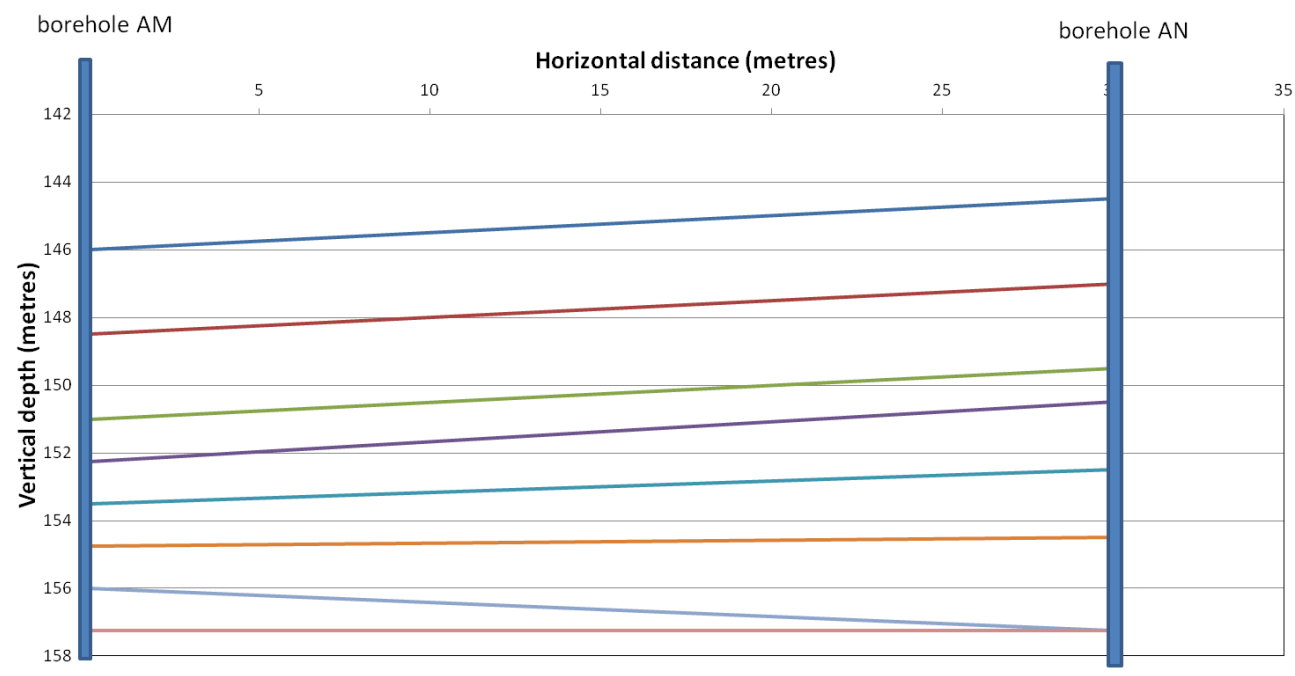

Figure 12. Fracture orientation and spacing implied by intersection and temperature logging data collected in borehole 101AN during fracturing of borehole 101 AM. The upper part of AM was fractured at $2.5 \mathrm{~m}$ vertical spacing which was reduced to $1.25 \mathrm{~m}$ spacing below $151 \mathrm{~m}$ depth.

\section{Conclusions}

Measurements of fracture growth, spacing and orientation at two trial sites and as the preconditioning of the Longwall 101 startup area was carried out demonstrated that the hydraulic fractures could be created that were essentially horizontal and could be extended to more than $30 \mathrm{~m}$ as parallel fractures. The tiltmeter data recorded during the trials and later during preconditioning, indicated dips of $2^{\circ}$ to $20^{\circ}$, which provided additional assurance that the fractures were essentially horizontal, especially at sites where no other monitoring was available. But attempts to analyse the tilt data for indications of asymmetric growth proved unreliable because the dip and dip direction are coupled to the location of the centre of fracture volume.

The theory of closely spaced fracture growth, developed using a 2D numerical model has been further verified by the measurments made during this project. The theory predicts that for the conditions at the Narrabri Coal site, hydraulic fractures placed sequentually at $1.25 \mathrm{~m}$ along a vertical borehole will grow with negligable curving to distance of $30 \mathrm{~m}$ or more, allowing the conglomerate roof rock to be preconditioned and weakened by placing fractures through its thickness. This was found to be the case, based on direct measurement of fracture arrival depths in offset boreholes.

The conglomerate caved soon after the start of Longwall 101, demonstrating the effectiveness of the intensive preconditioning carried out. 
Hydraulic fracturing can be used for preconditioning of strong roof sequences. When conditions allow horizontal fractures to be placed from vertical boreholes, the preconditioning can be carried out from the surface.

\section{Acknowledgements}

The work described in this paper was undertaken as part of the overall windblast management project funded by Narrabri Coal Operations. The authors thank Narrabri Coal, CSIRO, and SCT Operations for granting permission to publish these results.

\section{Author details}

R. G. Jeffrey ${ }^{1}$, Z. Chen ${ }^{1}$, K. W. Mills² and S. Pegg ${ }^{3}$

1 CSIRO Petroleum and Geothermal, Australia

2 SCT Operations Pty Ltd, Australia

3 Narrabri Coal Operations Pty Ltd, Australia

\section{References}

[1] Van As, A, \& Jeffrey, R. G. Caving induced by hydraulic fracturing at Northparkes Mines. In: J Girard, M. Liebman, C. Breeds, and T. Doe (Eds), The Fourth North American Rock Mechanics Symposium. 31 July- 3 August, (2000). Seattle, WA, USA. Rotterdam: A.A. Balkema.

[2] Chacon, E, Barrera, V, Jeffrey, R, \& Van As, A. Hydraulic fracturing used to precondition ore and reduce fragment size for block caving. In: A. Karzulovic and M.A. Alfaro (Eds), MassMin August, (2004). Santiago, Chile. Instituto de Ingenieros de Chile., 2004, 22-25.

[3] Bunger, A, Jeffrey, R, Kear, J, \& Zhang, X. Experimental investigation of the interaction among closely spaced hydraulic fractures. In 45th US Rock Mechanics / Geomechanics Symposium. June, (2011). San Francisco, CA, USA. ARMA., 26-29.

[4] Su DWHMcCaffrey JJ., Barletta L., Thomas EP., and Toothman RC. Hydraulic fracturing of sandstone and longwall roof control- implementation and evaluation. In S.S. Peng, C. Mark, and A.W. Khair (Eds), $20^{\text {th }}$ International Conference on Ground Control in Mining, August, (2001). Morgantown, W.V., USA., 7-9. 
[5] He, H, Dou, L, Fan, J, Du, T, \& Sun, X. Deep-hole directional fracturing of thick hard roof for rockburst prevention. Tunnelling and Underground Space Technology, doi: 10.1016/j.tust.(2012). , 32, 34-43.

[6] Jeffrey, R. G, \& Mills, K. W. Hydraulic fracturing applied to inducing longwall coal mine goaf falls. In: J Girard, M. Liebman, C. Breeds, and T. Doe (Eds), The Fourth North American Rock Mechanics Symposium. 31 July- 3 August, (2000). Seattle, WA, USA. Rotterdam: A.A. Balkema.

[7] Medhurst, T. Narrabri Coal Pty. Ltd. Longwall support geotechnical assessment. Report by PDR Engineers, May (2009). pp.(8760)

[8] Mills, K. W. In situ stress measurement using the ANZI stress cell. In: K. Sugawara and Y. Obara (Eds). The International Symposium on Rock Stress, October, (1997). Kumamoto, Japan. Rotterdam: A.A. Balkema., 7-10.

[9] Mills, K. W. Interpretation of in situ stress measurements conducted at the start of longwall 1 at Whitehaven. Report by SCT Operations Pty. Ltd., March (2011). pp.

[10] Gray, I. Narrabri coal in-situ stress test (IST). Report by Sigra Pty. Ltd., 8 May (2006).

[11] Lecampion, B, \& Peirce, A. Multipole moment decomposition for imaging hydraulic fractures from remote elastostatic data. Inverse Problems, (2007). doi:10.1088/

[12] Davis, P. V. Surface deformation associated with a dipping hydrofracture. Journal of Geophysical Research, (1983). B 88(7), 5826-5834.

[13] Lecampion, B, Jeffrey, R, \& Detournay, E. Resolving the geometry of hydraulic fractures from tilt measurements, Pure and Applied Geophysics, (2005). doi:10.1007/ s00024-005-2786-4., 2005(162), 12-2433.

[14] Chen, Z. R, \& Jeffrey, R. G. Tilt monitoring of hydraulic fracture preconditioning treatments. In the $43^{\text {rd }}$ U.S. Rock Mech. Symposium and $4^{\text {th }}$ U.S.-Canada Rock Mech. Symposium, Asheville, NC, 28 June- 1 July, (2009).

[15] Olson, J, Du, Y, \& Du, J. Tiltmeter data inversion with continuous, non-uniform opening distributions: A new method for detecting hydraulic fracture geometry. International Journal of Rock Mechanics and Mining Sciences, 34(3-4), 236.ee10. doi: 10.1016/S1365-1609(97)00120-2,(1997). , 1-236.

[16] Mills, K. W, Jeffrey, R. G, \& Zhang, X. Growth analysis and fracture mechanics based on measured stress change near a full-size hydraulic fracture. In the $6^{\text {th }}$ NARMS Symposium, GulfRock (2004). Houston, June, 2004., 6-10.

[17] Jeffrey, R. G, Settari, A, Mills, K. W, Zhang, X, \& Detournay, E. Hydraulic fracturing to induce caving: fracture model development and comparison to field data. In: D. Elsworth, J. P. Tinucci, and K. A. Heasley (Eds), DC Rocks: rock mechanics in the national interest: 38th U.S. Rock Mechanics Symposium, Jul 7-10, (2001). Washington, D.C. Lisse, Netherlands: Swets \& Zeitlinger, B., 251-260 
[18] Kear, J, White, J, Bunger, A. P, Jeffrey, R, \& Hessami, M. Three dimensional forms of closely-spaced hydraulic fractures, In: A.P. Bunger, J.D. McLennan, and R.G. Jeffrey (Eds), The International Conference for Effective and Sustainable Hydraulic Fracturing, May, (2013). Brisbane, Australia. InTech: Rijeka, Croatia., 20-22.

[19] Bunger, A. P, Zhang, X, \& Jeffrey, R. G. Parameters effecting the interaction among closely spaced hydraulic fractures. SPE Journal, (2012). , 17(1), 292-306. 